\title{
Post-Traumatic Headache: Is It A Danger?
}

\author{
Susanti, Restu ${ }^{1}$ \\ ${ }^{1}$ Bagian Saraf Fakultas Kedokteran Universitas Andalas/Rumah Sakit Umum Pusat dr. M. Djamil, Padang, \\ Indonesia
}

\begin{abstract}
Abstrak
Post-Traumatic Headache (PTH), merupakan keluhan paling sering setelah Traumatic Brain Injury (TBI). PTH sangat mempengaruhi kualitas hidup penderita. Post-Traumatic Headache didefinisikan sebagai nyeri kepala sekunder yang berkembang dalam 7 hari setelah trauma kepala (atau setelah mendapatkan kembali kesadaran setelah trauma kepala). Mekanisme secara pasti PTH masih belum diketahui, namun hipotesis dapat dimunculkan dari temuan klinis dan pemeriksaan diagnostik yang telah dilakukan. PTH dapat berasal dari perifer atau pusat. Pendekatan multidisiplin ditekankan dalam pengobatan PTH karena banyaknya gejala yang terkait. Artikel ini merupakan tinjauan pustaka yang membahas mengenai Post-Traumatic Headache mulai dari epidemiologi, etiopatogenesis, gejala klinis, dan tatalaksana
\end{abstract}

Katakunci: Post-Traumatic Headache

\begin{abstract}
Post-Traumatic Headache (PTH), is the most frequent complaint after Traumatic Brain Injury (TBI). PTH affects the quality of life of the sufferer. Post-traumatic headache is defined as secondary headache within 7 days after head trauma or after regained consciousness after head trauma. PTH's definitive mechanisms are still unknown, but hypotheses can be brought from clinical findings and diagnostic tests that have been conducted. PTH can originate from peripheral or central. A multidisciplinary approach is emphasized in the treatment of PTH due to the many associated symptoms.
\end{abstract}

Keywords: Post-Traumatic Headache

Email : heme@unbrah.ac.id 


\section{Pendahuluan}

Nyeri kepala adalah salah satu keluhan neurologis yang paling umum di seluruh dunia. Sekitar $50 \%$ populasi dunia mengalami nyeri kepala setiap tahunnya dan lebih dari $90 \%$ menyatakan pernah mengalami nyeri kepala. Cedera kepala merupakan cedera mekanik yang secara langsung atau tidak langsung mengenai kepala dan kerusakan jaringan otak yang mana mengakibatkan gangguan neurologi yang menyebabkan nyeri. ${ }^{+}$Nyeri kepala merupakan salah satu keluhan somatik yang sering muncul berkaitan dengan cedera kepala. ${ }^{2}$ Nyeri kepala pada pasien dengan cedera kepala dapat mengakibatkan nyeri kepala berat, berdenyut muntah, photophobia dan phonophobia. Pasien dengan cedera kepala dapat mengakibatkan kerusakan permanen pada jaringan otak seperti adanya iskemik otak. $^{3}$

Post-Traumatic Headache (PTH) dikaitkan dengan kecacatan dan penurunan kualitas hidup yang berhubungan dengan kesehatan. ${ }^{4}$ Post-Traumatic Headache (PTH) didefinisikan oleh International Headache Society sebagai timbulnya nyeri kepala dalam waktu tujuh hari setelah trauma atau cedera pada kepala dan / atau leher dan juga lebih lanjut ditandai sebagai akut (tiga bulan pertama onset) atau persisten (nyeri kepala bertahan lebih dari 3 bulan. ${ }^{5}$ PTH umumnya dikaitkan dengan banyak gejala termasuk pusing, susah tidur, konsentrasi yang buruk, masalah memori, sensitivitas terhadap kebisingan atau cahaya terang, kelelahan serta perubahan suasana hati dan kepribadian seperti depresi dan gugup. ${ }^{6}$

Beberapa penelitian menunjukkan bahwa nyeri kepala biasanya sembuh dalam waktu tiga bulan, namun, pada 18-65\% kasus, nyeri kepala ini dapat bertahan lebih lama dan kemudian disebut sebagai PTH persisten. $^{6}$ Data epidemiologis telah menunjukkan prevalensi PTH seumur hidup sebesar $4,7 \%$ pada pria dan $2,4 \%$ pada wanita, dengan nyeri kepala seperti migrain dan jenis-tegang menjadi fenotipe nyeri kepala yang paling umum. ${ }^{4,7}$ Selain itu, sejumlah besar pasien PTH mengalami pelemahan komorbiditas seperti gejala depresi, kecemasan, dan gangguan tidur. ${ }^{4}$ Sejumlah faktor dapat meningkatkan risiko PTH persisten termasuk nyeri kepala yang sudah ada, menjadi riwayat migrain perempuan dan keluarga. ${ }^{4}$ Trauma kepala berat tidak selalu menyebabkan nyeri kepala berkepanjangan karena pasien dengan trauma kepala ringan dapat menderita selama berbulan-bulan atau bertahun-tahun. ${ }^{6}$

Iskemik jaringan otak disebabkan oleh peningkatan metabolisme otak karena peningkatan penggunaan glukosa pada 30 menit pertama post trauma yang kemudian kadar glukosa akan dipertahankan lebih rendah dalam 5-10 hari. Peningkatan metabolisme glukosa berasal dari hiperglikolisis dari kekacauan gradien ionik membran sel dan aktivasi energi dari pompa ionik pada jaringan otak. Peningkatan metabolisme otak menyebabkan meningkatnya konsumsi oksigen otak oleh tubuh. Saat kebutuhan oksigen otak tidak terpenuhi maka metabolisme akan beralih dari aerob ke anaerob. Pada keadaan ini dihasilkan asam laktat yang menstimulasi terjadinya nyeri kepala. ${ }^{4}$ Peningkatan asam laktat dapat menyebabkan nyeri dikepala pada pasien cedera kepala. Vasodilatasi pembuluh darah pada otak menjadikan peningkatan serebral blood flow yang mana otak mengalami peningkatan suplai oksigen. Pengeluaran hormon endokrin yang berlebihan akibat dari pusat pengendalian pernafasan dikorteks serebri yang memacu kerja aktivitas saraf simpatis dan parasimpatis menyebabkan penurunan metabolisme sehingga pasien mengalami penurunan kebutuhan oksigen dalam otak. ${ }^{8}$

Perawatan farmakologis saat ini untuk PTH 
didasarkan pada obat-obatan akut atau preventif yang digunakan untuk gangguan nyeri kepala primer, karena PTH sering meniru fenotipe seperti nyeri kepala atau jenis-nyeri kepala seperti tegang., ${ }^{4,7}$ Pendekatan ini tidak memiliki bukti dan sering menghasilkan tanggapan pengobatan yang buruk. Selain itu, efek samping pada pengobatan farmakologis dapat bertentangan dengan komorbiditas PTH seperti depresi dan kecemasan. ${ }^{4}$

\section{EPIDEMIOLOGI}

Traumatic Brain Injury (TBI) adalah penyebab utama morbiditas dan disabilitas di seluruh dunia. Sekitar $80 \%$ dari TBI nonfatal diklasifikasikan sebagai TBI ringan. TBI ringan biasanya berkorelasi dengan kecelakaan kendaraan bermotor $(45 \%)$, jatuh (30\%), kecelakaan kerja (10\%), kecelakaan rekreasi $(10 \%)$, dan tindakan penyerangan $(5 \%)$. Sekitar $50 \%$ individu yang mengalami TBI ringan berusia 15-34 tahun. $^{2}$

\section{Post-Traumatic Headache (PTH) mencakup} sekitar $4 \%$ dari semua headache simptomatik. Intensitas PTH tidak menunjukkan hubungan yang signifikan dengan keparahan TBI, penyebab cedera atau dinamika trauma, yang berarti bahwa bahkan TBI yang relatif ringan dapat dikaitkan dengan gejala nyeri kepala yang berat. Data ini sejalan dengan ulasan terbaru yang melaporkan bahwa prevalensi CPTH mungkin lebih tinggi pada individu yang mengalami TBI ringan (75,3\%) dibandingkan pada mereka yang memiliki TBI berat $(32,1 \%)$. Tetapi secara umum, prevalensi PTH berada dalam rentang yang lebar, yaitu 30\%-90\% dari insidensi TBI. ${ }^{2}$

Diketahui bahwa kategori orang tertentu lebih rentan terhadap munculnya PTH. Meskipun laki-laki mengalami TBI ringan lebih sering daripada perempuan (dalam rasio setidaknya $2: 1$ ), tetapi kejadian PTH lebih besar pada perempuan. Perempuan juga memiliki risiko lebih tinggi mengalami TBI sedang-berat daripada TBI ringan. Selain itu, pada individu yang tidak memiliki nyeri kepala primer sebelumnya, PTH lebih cenderung terjadi pada tahun pertama pasca TBI ringan, yaitu sekitar $45 \%{ }^{2}$

\section{ETIOPATOGENESIS}

Mekanisme secara pasti post-traumatic headache (PTH) masih belum diketahui, namun hipotesis dapat dimunculkan dari temuan klinis dan pemeriksaan diagnostik yang telah dilakukan. PTH dapat berasal dari perifer atau pusat. Selain itu, efek dari biokimia yang dilepaskan saat terjadi trauma fisik akan menghasilkan nyeri dan efek terhadap kognitif. $^{11,12}$

Pada PTH yang berasal dari perifer, jaringan lunak perifer banyak yang menjadi potensi untuk terbentuknya nyeri kepala setelah cedera kepala traumatik. Hal ini dapat termasuk arteri intrakranial, duramater dan arteri dural, struktur ekstrakranial seperti tulang, otot, kulit, ligamen, dan fascia. Struktur-struktur ini diinervasi oleh reseptor nyeri (nosiseptor) yang terhubung fengan serat $\mathrm{C}$ dan A-delta. Kerusakan pada struktur tersebut dapat menyebabkan rantai kejadian yang berakhir dengan inflamasi neurogenik. Kejadian ini akan melepaskan sitokin dan kemokin yang akan mengaktifkan monosit selular dan infiltrasi, pengaktifan sel glia, dan melepaskan neuropeptida nosiseptif. ${ }^{11}$

Rusaknya vaskular akan berkembang dan nosiseptor di daerah yang terluka akan aktif dan tersensitisasi dan menjadi hiperresponsif terhadap stimulus dan mengakibatkan nyeri secara spontan. Walaupun sensitisasi nosiseptor intrakranial dan ekstrakranial biasanya dapat hilang secara spontan, nyeri dapat menetap dan menjadi nyeri kepala kronik. ${ }^{11}$

Mekanisme yang sama juga dapat terjadi pada nervus kranialis. Sebagai contoh, kerusakan langsung pada nervus trigeminal saat trauma dapat menyebabkan nyeri 
neuropati. Faktor lainnya pada patogenesis nyeri neuropati trigeminal adalah adanya kompresi abnormal pada nervus trigeminal oleh vena atau arteri, sistem trigeminovaskuler. Walaupun mekanisme endogen yang menyebabkan nosiseptor meningeal aktif masih belum sepenuhnya diketahui, inflamasi neurogenik dapat menjadi salah satu hipotesis. Inflamasi neurogenik memiliki karakteristik peningkatan aliran darah lokal, bocornya plasma protein dari pembuluh darah, degranulasi sel mast, dan agregrasi platelet. Satu stimulus untuk peradangan saraf dapat secara langsung mencederai saraf aferen trigeminal atau struktur leptomeningeal atau struktur serebrovaskular yang dipersarafi oleh nervus trigeminal dengan respon inflamasi lokal atau regional yang dimediasi oleh sel glia. Pengaktifan sel glia dengan peningkatan produksi substansi pro-inflamasi terlibat dalam terjadinya nyeri. Sitokin mengindukasi lepasnya modulator nyeri dari neuron trigeminal yang membantu jalur inflamasi dan neural. ${ }^{11,13,14}$

Patofisiologi nyeri yang terjadi di pusat masih belum sepenuhnya diketahui. Namun kerusakan pada sistem spinotalamikus/ thalamokortikal memiliki peran penting terhadap terjadinya nyeri. ${ }^{1}$ Beberapa mekanisme yang mungkin yaitu gangguan modulasi descending, perubahan neurometabolik, dan aktivasi sistem trigeminal. $^{14}$

Sistem modulasi nyeri yang menurun telah dikarakterisasi secara luas pada penelitian manusia dan hewan. Sistem ini menghubungkan beberapa sisi otak dan neuronal pathway. Gangguan pada modulasi nyeri ini menimbulkan kronifikasi nyeri yang mengarahkan kepada gangguan modulasi neuron hipereksitasi, bisa terjadi pada kasus migren mengingat kesamaan klinis. ${ }^{14}$

Remodelling struktur korteks serebri muncul berupa difus axonal injury akibat trauma pada kepala. Perubahan pada struktur serat jalur yang berasal dari kortikal otak (somatosensory dan insular korteks) dalam matriks nyeri merusak sistem modulasi nyeri descending seperti periaqueductal grey, inti raphe magnus, dan rostral medulla ventromedial. ${ }^{14}$

Data praklinis menunjukkan bahwa pada fase akut setelah trauma pada kepala melibatkan perubahan metabolik seluler dan aksonal yang luas, tergantung pada intensitas trauma. Trauma mekanis menyebabkan cedera seluler yang menginduksi pelepasan glutamate yang berlebihan dan fluks ion yang tidak teratur. Pompa ATP kemudian ditingkatkan untuk mengembalikan homeostasis ion. Proses ini dengan cepat menghabiskan sumber energi seluler dan ketidakseimbangan demand dan supply pada akhirnya akan menyebabkan akumulasi laktat dan stress oksidatif. Selain itu, peningkatan kalsium intraseluler dapat menyebabkan gangguan akson secara mekanis, memicu kaskade collapse neurofilament, dan pembongkaran mikrotubul yang mengakibatkan kerusakan struktur akson atau yang lebih dikenal axotomy sekunder. ${ }^{14}$

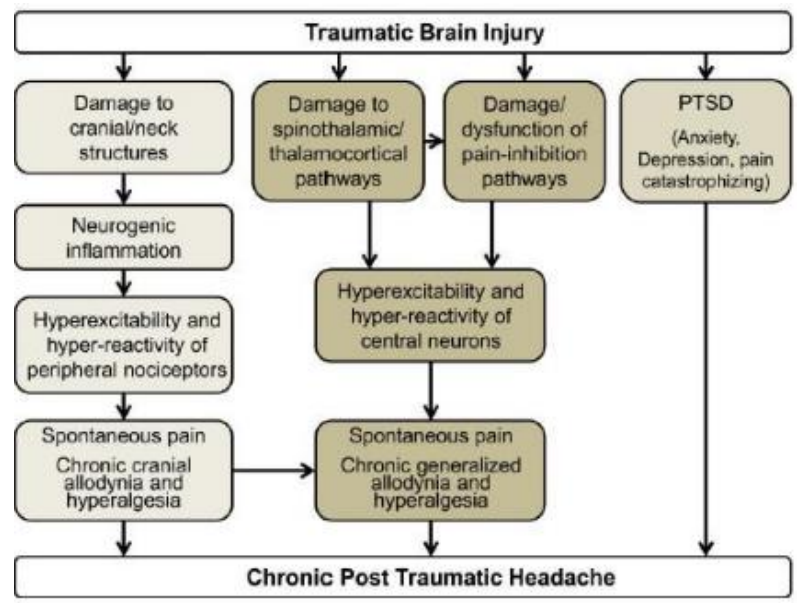

Gambar 1. Kemungkinan Mekanisme pada CPTH

\section{GeJala KLINIS}

Tidak ada karakteristik utama pada posttraumatic headache (PTH). Namun sering 
ditemukan nyeri kepala tipe tegang dan migrain, paling sering mengenai pelipis, lalu diikuti oleh kening, leher, belakang kepala, mata, dan vertex. Pada penelitian yang dilakukan pada tentara yang memiliki riwayat cedera kepala traumatik ringan dengan kehilangan kesadaran, cedera ledakan lebih sering dihubungkan dengan kejadian nyeri kepala persisten daripada mekanisme bukan ledakan. ${ }^{11,15}$

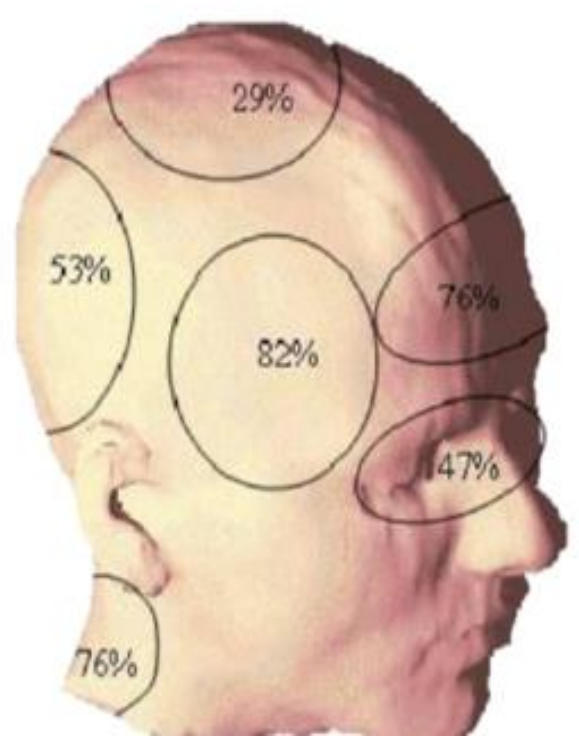

GAMbar 2. LokAsi Nyeri PAdA ORANG DENGaN PTH

Orang yang mengalami PTH seperti tipe tension mengeluhkan nyeri kepala bilateral dari intensitas ringan ke sedang dan semakin parah dengan adanya stres emosional dan tekanan. ${ }^{11}$ Sedangkan orang yang mengalami PTH tipe migrain akan mengeluhkan nyeri kepala unilateral dari intensitas sedang ke berat, terasa berdenyut dan terasa seperti tertusuk dan semakin parah pada saat aktifitas fisik. Orang ini dapat juga mengeluhkan sensitif terhadap cahaya terang atau suara. Frekuensi nyeri kepala dapat bervariasi pada setiap orang, dapat terjadi harian atau mingguan. Tiap episode nyeri kepala berlangsung dari beberapa menit hingga beberapa jam. Pada migrain, pusing dan vertigo dapat dihubungkan dengan kejadian PTH dan kemungkinan melalu mekanisme vestibular pusat atau perifer. ${ }^{11,15}$
Gejala yang timbul akibat konkusio akut menyerupai gejala pada migrain. Selain nyeri kepala, mual, sensorik yang sensitif, kelelahan, sulit konsentrasi, pusing, dan iritabilitas sering terjadi pada sindrom setelah konkusio dan migrain. ${ }^{15}$

\section{Tabel 1. Gejala Klinis PTH}

\begin{tabular}{|c|c|c|c|c|}
\hline & \multicolumn{2}{|c|}{ Tension Migraine } & \multirow{2}{*}{$\begin{array}{l}\text { Cluster } \\
\text { Like }\end{array}$} & \multirow{2}{*}{$\begin{array}{l}\text { Cervicog } \\
\text { enic Like }\end{array}$} \\
\hline & $\begin{array}{l}\text { Type } \\
\text { Like }\end{array}$ & $\begin{array}{l}\text { Type } \\
\text { Like }\end{array}$ & & \\
\hline Sidedness & Bilateral & Unilateral & Unilateral & $\begin{array}{c}\text { Mainly } \\
\text { unilateral }\end{array}$ \\
\hline Intensity & $\begin{array}{c}\text { Mild- } \\
\text { Moderate }\end{array}$ & $\begin{array}{c}\text { Moderate- } \\
\text { Severe }\end{array}$ & $\begin{array}{c}\text { Severe- } \\
\text { very } \\
\text { severe }\end{array}$ & $\begin{array}{l}\text { Mild- } \\
\text { severe }\end{array}$ \\
\hline Quality & $\begin{array}{l}\text { Pressing, } \\
\text { dull, } \\
\text { squeezing }\end{array}$ & $\begin{array}{l}\text { Pounding, } \\
\text { throbbing, } \\
\text { drilling, } \\
\text { piercing }\end{array}$ & $\begin{array}{l}\text { Boring, } \\
\text { throbbing }\end{array}$ & $\begin{array}{c}\text { Aching, } \\
\text { dull }\end{array}$ \\
\hline Location & Vary & Vary & $\begin{array}{c}\text { Retro/Peri } \\
\text { orbital }\end{array}$ & $\begin{array}{l}\text { Starts in } \\
\text { the neck } \\
\text { and } \\
\text { spread to } \\
\text { anterior } \\
\text { region }\end{array}$ \\
\hline $\begin{array}{l}\text { Aggrevated } \\
\text { By Other } \\
\text { Features }\end{array}$ & $\begin{array}{c}\text { Emotional } \\
\text { stress, } \\
\text { tension } \\
\text { Can be } \\
\text { episodic } \\
\text { or } \\
\text { contanious }\end{array}$ & $\begin{array}{l}\text { Physical } \\
\text { activity, } \\
\text { Photophob } \\
\text { ia/phonop } \\
\text { obia, } \\
\text { Vomiting, } \\
\text { With/witho } \\
\text { ut aura }\end{array}$ & $\begin{array}{c}\text { Alcohol, } \\
\text { cranial } \\
\text { autonomic } \\
\text { activtion }\end{array}$ & $\begin{array}{c}\text { Neck } \\
\text { movement } \\
\text { or posture, } \\
\text { other } \\
\text { history of } \\
\text { whiplash }\end{array}$ \\
\hline
\end{tabular}

\section{Diagnosis}

Klasifikasi International Classification of Headache (ICHD) untuk PTH dikhususkan untuk nyeri kepala yang disebabkan oleh trauma atau cedera pada kepala dan / atau leher (point 5 dalam ICHD). Dua perbedaan utama yang membagi gangguan ini adalah durasi kondisi nyeri kepala setelah cedera (akut dan persisten) dan keparahan cedera (sedang hingga berat dan ringan) yang menyebabkan atau meningkatkan pola nyeri kepala secara tiba-tiba. ${ }^{16}$

Perbedaan pertama dalam klasifikasi PTH adalah antara PTH akut (durasi kurang dari 3 
bulan) dan PTH persisten (durasi lebih dari 3 bulan). Saat ini tidak ada karakteristik pada permulaan PTH yang dapat memprediksi hasil PTH secara baik untuk akut atau persisten. $^{16}$

Perbedaan kedua dalam klasifikasi ICHD untuk PTH adalah tingkat keparahan nyeri kepala berdasarkan cedera yang mendasari (tabel 2). Klasifikasi berbasis gejala sangat diperlukan untuk memfasilitasi penentuan terapi yang efektif untuk PTH. Dari perspektif desain uji klinis yang pernah dilakukan, klasifikasi berdasarkan gejala populasi dengan PTH akan memberikan gambaran akhir yang terukur dan relevan secara klinis. Secara khusus, profil gejala PTH termasuk serangkaian serangan episodik yang mungkin juga termasuk adanya nyeri kepala terus menerus. ${ }^{16}$

\section{TABEL 2. KLASIFIKASI ICHD UNTUK PTH}

\begin{tabular}{l}
\hline 5.1 Nyeri kepala akut yang dikaitkan dengan \\
cedera traumatis pada kepala \\
5.1.1 Nyeri kepala akut yang disebabkan \\
oleh cedera traumatis sedang atau berat pada \\
kepala \\
5.1.2 Nyeri kepala akut yang disebabkan \\
oleh cedera traumatis ringan pada kepala \\
\hline 5.2 Nyeri kepala persisten yang dikaitkan dengan \\
cedera traumatis ke kepala \\
5.2.1 Nyeri kepala persisten yang dikaitkan \\
dengan cedera traumatis sedang atau berat \\
pada kepala \\
5.2.2 Nyeri kepala persisten yang dikaitkan \\
dengan cedera traumatis ringan pada kepala \\
\hline 5.3 Nyeri kepala akut yang dikaitkan dengan \\
whiplash \\
\hline 5.4 Nyeri kepala persisten yang dikaitkan dengan \\
whiplash \\
\hline 5.5 Nyeri kepala akut yang dikaitkan dengan \\
kraniotomi \\
\hline 5.6 Nyeri kepala persisten yang dikaitkan dengan \\
kraniotomi
\end{tabular}

1. Nyeri kepala akut yang disebabkan oleh cedera traumatis di kepala.

Durasi kurang dari 3 bulan yang disebabkan oleh cedera traumatis pada kepala.

Kriteria diagnostik:
A. Setiap kriteria nyeri kepala memenuhi kriteria $C$ dan $D$

B. Cedera traumatis pada kepala1 telah terjadi

C. Nyeri kepala dilaporkan telah berkembang dalam 7 hari setelah salah satu dari yang berikut:

1. Cedera pada kepala

2. Sadar kembali setelah cedera kepala

3. Penghentian pengobatan yang mengganggu kemampuan untuk merasakan atau melaporkan nyeri kepala setelah cedera pada kepala

D. Salah satu dari yang berikut:

1. Nyeri kepala telah sembuh dalam 3 bulan setelah cedera pada kepala

2. Nyeri kepala belum sembuh tetapi 3 bulan belum berlalu sejak cedera pada kepala

2. Nyeri kepala akut yang disebabkan oleh cedera traumatis sedang atau berat pada kepala

Kriteria diagnostik:

A. Kriteria memenuhi nyeri kepala untuk nyeri kepala akut yang dikaitkan dengan cedera traumatis pada kepala

B. Cedera pada kepala terkait dengan setidaknya satu dari yang berikut:

1. Kehilangan kesadaran selama $>30$ menit

2. Skor Glasgow Coma Scale (GCS) < 13

3. Amnesia post-traumatik yang berlangsung $>24$ jam

4. Perubahan tingkat kesadaran $>24$ jam

5. Bukti pencitraan dari cedera kepala traumatis seperti perdarahan intrakranial dan / atau memar otak.

3. Nyeri kepala akut pasca-trauma yang disebabkan oleh cedera traumatis ringan pada kepala.

Kriteria diagnostik:

A. Kriteria pemenuhan nyeri kepala untuk Nyeri kepala akut yang dikaitkan dengan cedera traumatis pada kepala 
B. Cedera pada kepala yang memenuhi kedua hal berikut:

1. terkait dengan tidak ada hal berikut:

a. kehilangan kesadaran selama> 30 menit

b. Skor Glasgow Coma Scale (GCS) $<13$

c. amnesia pasca-trauma yang berlangsung $>24$ jam

d. tingkat kesadaran yang berubah selama > 24 jam

e. bukti pencitraan dari cedera kepala traumatis seperti perdarahan intrakranial dan / atau kontusio otak

2. terkait, segera setelah cedera kepala, dengan satu atau lebih gejala dan / atau tanda berikut:
a. kebingungan sementara, disorientasi atau gangguan kesadaran

b. kehilangan ingatan untuk acaraacara segera sebelum atau setelah cedera kepala

c. dua atau lebih gejala lain yang menunjukkan cedera otak traumatis ringan: mual, muntah, gangguan penglihatan, pusing dan I atau vertigo, gangguan memori dan / atau konsentrasi.

4. Nyeri kepala persisten yang disebabkan oleh cedera traumatis pada kepala

Keterangan: Nyeri kepala dengan durasi lebih dari 3 bulan disebabkan oleh cedera traumatis pada kepala.

Kriteria diagnostik:

A. Setiap kriteria nyeri kepala memenuhi kriteria C dan D

B. Cedera traumatis pada kepala1 telah terjadi

C. Nyeri kepala dilaporkan telah berkembang dalam 7 hari setelah salah satu dari yang berikut:

1. Cedera pada kepala

2. Sadar kembali setelah cedera kepala

3. Penghentian pengobatan yang mengganggu kemampuan untuk merasakan atau melaporkan nyeri kepala setelah cedera pada kepala

D. Nyeri kepala berlangsung selama $>3$ bulan setelah cedera pada kepala

5. Nyeri kepala persisten yang disebabkan oleh cedera traumatis sedang atau berat pada kepala

Kriteria diagnostik:

A. Kriteria pemenuhan nyeri kepala untuk nyeri kepala persisten yang dikaitkan dengan cedera traumatis pada kepala

B. Cedera pada kepala terkait dengan setidaknya satu dari yang berikut:

1. kehilangan kesadaran selama> 30 menit

2. Skor Glasgow Coma Scale (GCS) $<13$

3. Amnesia post-traumatik yang berlangsung $>24$ jam

4. Perubahan tingkat kesadaran $>24$ jam

5. Bukti pencitraan dari cedera kepala traumatis seperti perdarahan intrakranial dan / atau memar otak.

6. Nyeri kepala persisten yang disebabkan oleh cedera traumatis ringan pada kepala Kriteria diagnostik:

A. Kriteria pemenuhan nyeri kepala untuk nyeri kepala persisten yang dikaitkan dengan cedera traumatis pada kepala

B. Cidera kepala memenuhi kedua hal berikut:

1. Terkait dengan tidak ada hal berikut:

a. kehilangan kesadaran selama> 30 menit

b. Skor Glasgow Coma Scale (GCS) $<13$

c. amnesia pasca-trauma yang berlangsung $>24$ jam

d. tingkat kesadaran yang berubah selama> 24 jam

e. bukti pencitraan dari cedera kepala traumatis seperti perdarahan intrakranial dan / atau kontusio otak 
2. Terkait, segera setelah cedera kepala, dengan satu atau lebih gejala dan / atau tanda berikut:
a. kebingungan disorientasi atau gangguan kesadaran
b. kehilangan ingatan untuk acara- acara segera sebelum atau setelah cedera kepala

c. dua atau lebih gejala lain yang menunjukkan cedera otak traumatis ringan: mual, muntah, gangguan penglihatan, pusing dan / atau vertigo, gangguan memori dan / atau konsentrasi.

7. Nyeri kepala akut yang dikaitkan dengan whiplash: nyeri kepala dengan durasi kurang dari 3 bulan yang disebabkan oleh whiplash. Whiplash didefinisikan sebagai gerakan akselerasi / deselerasi kepala yang tiba-tiba dan tidak cukup tertahan dengan fleks / ekstensi leher. Whiplash dapat terjadi setelah kekuatan tumbukan tinggi atau rendah.

Kriteria diagnostik:
A. Setiap kriteria nyeri kepala memenuhi kriteria $\mathrm{C}$ dan $\mathrm{D}$
B. Whiplash, terkait pada saat itu dengan nyeri leher dan / atau nyeri kepala, telah terjadi
C. Nyeri kepala telah berkembang dalam 7 hari setelah whiplash
D. Salah satu dari yang berikut:
1. Nyeri kepala telah sembuh dalam 3 bulan setelah whiplash
2. Nyeri kepala belum sembuh tetapi 3 bulan belum berlalu sejak whiplash

8. Nyeri kepala persisten yang disebabkan oleh whiplash: nyeri kepala dengan durasi lebih dari 3 bulan disebabkan oleh whiplash.

Kriteria diagnostik:
A. Setiap kriteria memenuhi kriteria $\mathrm{C}$ dan $\mathrm{D}$

B. Whiplash, terkait pada saat itu dengan nyeri leher dan / atau nyeri kepala, telah terjadi

C. Nyeri kepala telah berkembang dalam 7 hari setelah whiplash

D. Nyeri kepala berlangsung selama> 3 bulan setelah whiplash E. Tidak lebih baik diperhitungkan dengan diagnosis ICHD-3 lainnya.

9. Nyeri kepala akut yang dikaitkan dengan kraniotomi

Nyeri kepala dengan durasi kurang dari 3 bulan yang disebabkan oleh kraniotomi bedah.

Kriteria diagnostik:

A. Setiap kriteria nyeri kepala memenuhi kriteria $\mathrm{C}$ dan $\mathrm{D}$

B. Kraniotomi bedah telah dilakukan. Ketika kraniotomi dilakukan setelah cedera kepala, beri kode sebagai nyeri kepala akut yang dikaitkan dengan cedera traumatis sedang atau berat pada kepala.

C. Nyeri kepala dilaporkan telah berkembang dalam 7 hari setelah salah satu dari yang berikut:

1. Kraniotomi

2. Sadar kembali setelah kraniotomi

3. Penghentian pengobatan yang mengganggu kemampuan untuk merasakan atau melaporkan nyeri kepala setelah kraniotomi

D. Salah satu dari yang berikut:

1. Nyeri kepala telah sembuh dalam 3 bulan setelah kraniotomi

2. Nyeri kepala belum sembuh tetapi 3 bulan belum berlalu sejak kraniotomi

3. Tidak diperhitungkan dengan lebih baik oleh diagnosis ICHD-3 lainnya

10. Nyeri kepala persisten yang dikaitkan dengan kraniotomi: nyeri kepala dengan durasi lebih dari 3 bulan yang disebabkan oleh kraniotomi bedah.

Kriteria diagnostik: 
A. Setiap kriteria nyeri kepala memenuhi kriteria $\mathrm{C}$ dan $\mathrm{D}$

B. Kraniotomi bedah telah dilakukan. Ketika kraniotomi dilakukan setelah cedera kepala, beri kode sebagai nyeri kepala persisten yang dikaitkan dengan cedera traumatis sedang atau berat pada kepala

C. Nyeri kepala dilaporkan telah berkembang dalam 7 hari setelah salah satu dari yang berikut:

1. Kraniotomi

2. Sadar kembali setelah kraniotomi

3. Penghentian pengobatan yang mengganggu kemampuan untuk merasakan atau melaporkan nyeri kepala setelah kraniotomi

D. Nyeri kepala berlangsung selama > 3 bulan setelah kraniotomi

\section{Vi. Pemeriksaan Penunjang}

\section{PemeriksaAn Laboratorium}

Tes darah yang memprediksi dengan akurasi $>99 \%$ apakah ada perdarahan intrakranial atau tidak setelah TBI. Ini kemungkinan akan memiliki dampak yang diinginkan mengurangi jumlah individu yang terpapar radiasi dan mengurangi biaya medis. ${ }^{18}$

\section{PEMERIKSAAN RADIOLOGI}

\section{CT SCAN}

Pencitraan kepala dan otak pada cedera traumatik tidak selalu diindikasikan, tetapi CT Scan dapat menilai lesi kranial yang dapat dijumpai pada cedera traumatik yang sudah berat. CT Scan kepala adalah modalitas pencitraan yang paling sering digunakan dalam kondisi akut. CT Scan dapat mengidentifikasi pasien dengan lesi kranial berat seperti perdarahan intrakranial, patah tulang, dan edema serebral, serta kondisi yang dapat memerlukan intervensi akut. Indikasi untuk dilakukannya CT Scan kepala adalah dengan misalnya, adanya nyeri kepala pada pasien dengan TBI ringan yang juga memiliki kehilangan kesadaran atau amnesia, mungkin disarankan untuk perlunya pencitraan akut. ${ }^{18}$

\section{MRI}

Untuk melihat kepadatan, volume, dan ketebalan berbagai wilayah otak dapat ditentukan dari pencitraan $T 1$-weighted rutin menggunakan teknik pasca-pemrosesan canggih. Secara umum, pengukuran yang lebih rendah dari normal dianggap mencerminkan kehilangan integritas, dan nilai-nilai yang lebih besar dari biasanya dianggap mencerminkan peningkatan fungsionalitas atau reorganisasi mungkin karena peningkatan regulasi atau peningkatan pemanfaatan area. Kehilangan volume multifokal dan penipisan kortikal telah ditunjukkan pada pasien kelompok TBI ringan. ${ }^{19}$

Pertimbangan MRI atau CT angiogram diseksi arteri, aneurisma, vasospasme, atau carotid cavernosus fistula dan pertimbangan pada pasien dengan kemungkinan trombosis vena serebral. MRI cervical spine juga diduga jika mengarah pada nyeri kepala servikogenik. ${ }^{19}$

\section{VII.TATA LAKSANA}

Pendekatan multidisiplin ditekankan dalam pengobatan PTH karena banyak gejala yang terkait. Hingga saat ini belum terdapat tatalaksana farmakologis yang evidence based dalam tatalaksana nyeri kepala khusus untuk PTH. Sebelum pelaksanaan rencana tatalaksana apa pun, dokter harus melakukan evaluasi yang komprehensif dan sistematis. ${ }^{20}$, 21

Terapi profilaksis untuk presentasi migrain atau tipe-tegang meliputi pendekatan standar dengan $\beta$-blocker, antidepresan, atau obat antiepilepsi. Sampai saat ini, hanya terdapat tiga penelitian yang dilakukan tanpa kontrol menyelidiki profilaksis medis PTH. Masingmasing studi ini, yang melibatkan pendekatan tunggal atau ganda yang terdiri dari propranolol, amitriptyline, atau asam valproat, menunjukkan kemanjuran yang signifikan secara statistik. ${ }^{20,21}$ 
Untuk serangan akut dan eksaserbasi, NSAID, analgesik sederhana, dan triptan adalah opsi lini pertama yang biasa tergantung pada jenis nyeri kepala. Dokter harus mewaspadai potensi nyeri kepala akibat penggunaan obat yang berlebihan berupa penggunaan obat bebas yang mengandung kafein. Nyeri kepala akibat penggunaan obat-obatan juga dapat terjadi akibat penggunaan ergotamin, triptans, dan mungkin OAINS yang berlebihan. Obat resep yang mengandung narkotika, butalbital, atau benzodiazepin umumnya digunakan dengan hati-hati dan dengan hatihati karena risiko penyalahgunaan, pembiasaan, dan nyeri kepala karena penggunaan obat yang berlebihan. ${ }^{20}$

Suntikan titik pemicu dan blok saraf oksipital mungkin efektif. Loder dan Biondi dalam studinya melaporkan injeksi toksin botulinum bermanfaat untuk PTH kronis. Tatalaksana nonfarmakologis meliputi terapi fisik dan manipulasi; biofeedback dan terapi relaksasi, stimulator saraf transkutan, dan terapi kognitif dan perilaku. Studi prospektif dari tatalaksana yang ada dan pendekatan baru sangat diperlukan untuk manajemen yang lebih efektif. ${ }^{20}$

Keluhan kebanyakan pasien dengan PTH persisten dan gejala pascakonsepsi lain sering diminimalisir secara tidak tepat oleh tenaga kesehatan, anggota keluarga, dan rekan kerja. Mereka mungkin mengalami cedera kepala ringan dengan trauma eksternal minimal jika ada dan tampak baikbaik saja. $^{20}$

Edukasi tentang TBI ringan dan nyeri kepala adalah bagian penting dari tatalaksana. Dokter juga dapat menggunakan contohcontoh yang lebih familiar seperti dari olahraga dan atlet terkenal yang harus pensiun karena PTH seperti Troy Aikman dan Pat Lafontaine, yang ironisnya memberikan kredibilitas tertentu pada laporan media dan ketertarikan publik dengan atlet elit. Perhatian terhadap cedera tentara AS baru-baru ini juga meningkatkan kesadaran. $^{20}$

\section{KESIMPULAN}

Post-Traumatic Headache (PTH), merupakan keluhan paling sering setelah Traumatic Brain Injury (TBI), mencakup sekitar 4\% dari semua headache simptomatic. Intensitas PTH tidak menunjukkan hubungan yang signifikan dengan keparahan TBI, penyebab cedera atau dinamika trauma. Mekanisme secara pasti PTH masih belum diketahui, namun hipotesis dapat dimunculkan dari temuan klinis dan pemeriksaan diagnostik yang telah dilakukan. Pencitraan kepala dan otak pada cedera traumatik tidak selalu diindikasikan, tetapi CT Scan dapat menilai lesi kranial yang dapat dijumpai pada cedera traumatik yang sudah berat. Pendekatan multidisiplin ditekankan dalam pengobatan PTH karena banyaknya gejala yang terkait.

\section{DAfTar Pustaka}

[1] Esther IM, Miranda, Maximillian Ch. O \& Limpeleh, Hilman. Gambaran CT scan kepala pada penderita cedera kepala ringan di BLU RSUP Prof. Dr. R. D. Kandou Manado Periode 2012 - 2013. Jurnal e-CliniC (eCl). 2014: 2(2).

[2] Trevana L \& Cameron I. Traumatic Brain Injury Long Term Care of Patients in General Practice. Focus Neurology. 2011: XL (12). p956-960.

[3] Rahayu, Urip, dkk. Pengaruh Guided Imagery Relaxation Terhadap Nyeri Kepala Pasien Cedera Kepala. 2013. Diakses pada 15 Juni 2020.

[4] Eigil LL, Håkan A, Afrim I, Haidar M AlKhazali, Kristoffer T, Messoud A, Sait A, \& Henrik WS. Acute and preventive pharmacological treatment of post-traumatic headache: a systematic review. The Journal of Headache and Pain. 2019: 20 (98) https://thejournalofheadacheandpain.biomedce ntral.com/articles/10.1186/s10194-019-1051-7 diakses pada 16 Juni 2020.

[5] Lucas S. Posttraumatic headache: clinical characterization and management. Curr Pain Headache Rep. 2015; 19(10):1-9

[6] Lagman-Bartolome AM. Post-Traumatic Headache. Department of Pediatric Neurology University of Toronto; 2016. 
https://americanmigrainefoundation.org/resour ce-library/post-traumatic-headache/ diakses pada 16 Juni 2020.

[7] Ashina H, Porreca F, Anderson T, Mohammad Amin F, Ashina M, Winther Schytz, dkk. Post-traumatic headache: epidemiology and pathophysiological insights. Nat Rev Neurol. 2019

[8] Gina R.Asuhan Keperawatan pada Tn.F dengan Cedera Kepala ringan dan fraktur 1/3 proximal radius ulna dengan aplikasi Guided Imagery untuk menurunkan nyeri di ruangan Recovery Room (RR) Bedah RSUP Dr. M. Djamil Padang. Padang: Fakultas Kedokteran Universitas Andalas; 2018. http://scholar.unand.ac.id/38224/ diakses pada 16 Juni 2020

[9] Tarwoto. Keperawatan medikal bedah gangguan sistem persarafan. Jakarta: Sagung Seto; 2012.

[10] Smeltzer et al. Buku ajar keperawatan medikal bedah bruner \& suddarth edisi 8. Jakarta: EGC; 2013.

[11] Defrin R. Chronic post-traumatic headache: clinical findings and possible

[12] Mechanisms. Journal of Manual and Manipulative Therapy. 2014, 22: 36-43.

[13] D’Onofrio F, Russo A, Conte F, Casucci G, Tessitore A, Tedeschi G. Post-traumatic headaches: an epidemiological overview. Neuro Sci. 2014, 35; 203-206.

[14] Mayer CL, Huber BR, Peskind E. Traumatic brain injury, neuroinflammation, and posttraumatic headaches. J Headache Pain. 2013; 1523-30.

[15] Ashina H, Porreca F, Anderson T, Amin FM, Ashina M, Schytz HW. Post-traumatic headache: epidemiology and pathophysiological insights. Nature Reviews Neurology. 2019; 15, 607-17.

[16] Kamins J, Charles A. Posttraumatic headache: basic mechanisms and therapeutic targets. J Headache Pain. 2018; 58(6), 811-26.

[17] Lucas S, Ahn AH. Posttraumatic Headache: Classification by Symptom-Based

[18] Clinical Profiles. Washington: American Headache Society; 2018:1-9.

[19] Headache Classification Subcommittee of the International Headache Society. The International Classification of Headache Disorders: 3rd edition (Beta Version). Cephalalgia. 2013;33(9):683-91.

[20] Jill C. Rau1 \& Gina M. Dumkrieger1 \& Catherine D. Chong1 \& Todd J. Schwedt : Imaging Post-Traumatic Headache, Pain Med 2018, 22:64

[21] Holle D, Obermann M: The role of neuroimaging in the diagnosis of headache disorders. Therapeutic Advances in
Neurological Disorder. 2013 Nov; 6(6): 369374.

[22] Tad D, Seifert. Randolph W, Evans. Posttraumatic Headache: A review. Curr Pain Headache Rep. 2014;14(8): 110-7.

[23] Lindekilde L, Eigil et.al. Acute and Preventive Pharmacological Treatment of Post-traumatic headache: a systematic review. 2019;20(98): 1051

Email : heme@unbrah.ac.id 